\title{
PENGARUH EKSPOR IMPOR KAKAO DAN KARET TERHADAP CADANGAN DEVISA DI INDONESIA
}

\author{
Mustafa $^{* a}$, Devi Andriyani ${ }^{* b}$ \\ *Fakultas Ekonomi dan Bisnis Universitas Malikussaleh \\ a. Corresponding author:mustafaandra496@gmail.com \\ b. Devisep80@gmail.com
}

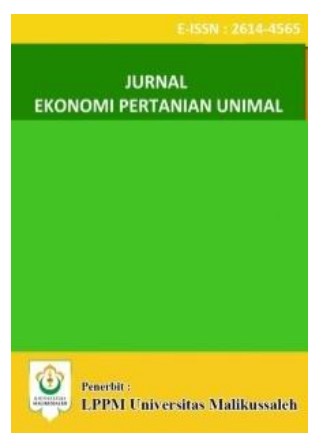

\section{$\underline{\text { A R T I CLE I N F O RMA T I O N A B S T R A C T }}$}

Keywords:

Cocoa, Rubber, Import Exports,

Foreign Exchange Reserves .
This study aims to analyze the effect of cocoa and rubber export imports on foreign exchange reserves in Indonesia. This study uses secondary data from 2005-2017 obtained from the Central Bureau of Statistics of Indonesia. The data analysis method used multiple linear regression models. The results partially show that cocoa and rubber export impors do not significantly influence the foreign exchange reserves in Indonesia. Simultaneous cocoa and rubber export imports have a positive and significant effect on foreign exchange reserves in Indonesia. The amount of influence is 0,9059 or 90,59\% while the rest is influenced by other variables outside the model by $09,41 \%$.

\section{PENDAHULUAN}

Pada zaman yang sangat modern seperti sekarang ini, pasar bebas dan perdagangan bebas selalu menjadi titik utama untuk negaranegara dalam bersaing di dunia internasional. Indonesia adalah negara berkembang yang menjadikan perdagangan internasional sebagai salah satu kegiatan penting dalam perekonomian. Perdagangan internasional merupakan kegiatan penduduk dari satu negara dengan negara yang lain, yang telah disepakati bersama dan atas prinsip sukarela, itu terjadi tanpa ada unsur paksaan dari pihak manapun. Perdagangan diantar negara ini dilakukan karena suatu negara yang tidak mampu untuk mengatasi kebutuhan hidupnya yaitu menghasilkan barang atau jasa, karena keterbatasan nya dan kelangkaan sumber daya nya, baik itu sumber daya alam maupun sumber daya manusia, sehingga dapat mendorong sebuah negara untuk melakukan nya perdagangan yang disebut dengan kegiatan ekspor dan impor barang dan jasa.

Dengan terjadinya aktivitas ekspor dan impor pemerintah mampu memperoleh pendapatan dalam bentuk devisa. Semakin tinggi aktivitas ekspor yang terjadi, semakin besar pula devisa yang diperoleh oleh negara tersebut. Barang-barang yang diekspor oleh Indonesia antara lain terdapat dua macam yakni minyak bumi dan gas alam, dan selain minyak bumi dan gas alam (nonmigas). Barang-barang yang bukan migas di antaranya merupakan hasil perkebunan dan pertanian, contohnya kakao, dan karet.

Selain aktivitas ekspor, aktivitas impor juga memiliki efek terhadap perekonomian sebuah negara dan masyarakatnya. Menurut Ekanada (2014), untuk menjaga produsen yang lemah di dalam suatu negeri, biasanya negara membatasi jumlah impor. Selain untuk menjaga produsen didalam negeri, batasan impor juga memiliki dampak lebih luas terhadap perekonomian di suatu negara. Dampak positif yang membatasi impor tersebut secara umum yaitu menumbuhkan suatu rasa cinta terhadap produk di buatan negeri, meminimkan keluarnya cadangan devisa ke luar negeri, dan juga mengurangi sikap kecanduan terhadap barang yang impor, serta memperkuat posisi di neraca pembayaran. Posisi suatu cadangan devisa negara dikatakan terkendali apabila telah memenuhi kebutuhan impor dalam kurun waktu setidaknya tiga bulan impor. Dampak positif nya dan negatif nya terhadap cadangan devisa di satuu negara banyak bergantung pada seberapa besar kemampuan ekspor negara tersebut dibanding dengan kekuatan impornya. 
Hubungan suatu ekspor terhadap cadangan devisa ialah didalam melakukan ekspor, maka negara tersebut akan mendapatkan berupa nilai sebanyak uang didalam valuta asing sering disebut dengan devisa, yakni salah satu untuk sumber pemasukan di negara. Jadi apabila tingkat suatu ekspor mengalami penurunan, maka akan diikuti juga dengan ikut menurunnya cadangan devisa yang tersedia.

Hubungan suatu impor dengan cadangan devisa yaitu impor ditentukan oleh kesanggupannya atau kemampuannya didalam menghasilkan barang-barang yang bersaing dengan barang yang diluar negeri.

Selain itu, suatu perusahaan yang mengerjakan impor maka akan memerlukan jumlah devisa yang lebih banyak untuk membayar transaksi tersebut. Sehingga ketersediaannya devisa suatu negara akan mempunyai peranan yang penting dalam impor, mengingat bahwa di sebuah negara akan melakukan impor disebabkan produksi didalam negeri tidak akan bisa memenuhi kebutuhan sendiri atau mungkin negara itu sendiri tidak mampu memproduksinya. Dengan terhentinya kegiatan impor maka akan ikut juga terhentinya kegiatan di dalam suatu negara.

Dibawah ini disajikan data cadangan devisa nya, ekspor impor kakao dan karet.

\section{Tabel 1}

\section{Cadangan devisa, Ekspor Impor Kakao dan Karet}

\begin{tabular}{|c|c|c|c|c|c|}
\hline \multirow[t]{2}{*}{ Tahun } & \multirow{2}{*}{$\begin{array}{c}\text { CadanganD } \\
\text { evisa(Juta } \\
\text { US\$) }\end{array}$} & \multicolumn{2}{|c|}{$\begin{array}{c}\text { Ekspor(Juta } \\
\text { US\$) }\end{array}$} & \multicolumn{2}{|c|}{ Impor(Juta US\$) } \\
\hline & & Kakao & Karet & Kakao & Karet \\
\hline 2014 & 111.862 & $\begin{array}{l}1.244 .5 \\
30\end{array}$ & $\begin{array}{l}4741 \\
489\end{array}$ & $\begin{array}{l}469.00 \\
5\end{array}$ & 48366 \\
\hline 2015 & 105.931 & $\begin{array}{l}1.307 .7 \\
71\end{array}$ & $\begin{array}{l}3.699 \\
.055\end{array}$ & $\begin{array}{l}293.78 \\
0\end{array}$ & 41.159 \\
\hline 2016 & 116.362 & $\begin{array}{l}1.239 \\
581\end{array}$ & $\begin{array}{l}3.370 \\
341\end{array}$ & $\begin{array}{l}350 \\
372\end{array}$ & 32647 \\
\hline 2017 & 130.196 & $\begin{array}{l}1 \\
765\end{array}$ & $\begin{array}{l}5102 \\
200\end{array}$ & $\begin{array}{l}640 \\
337 \\
\end{array}$ & 41527 \\
\hline
\end{tabular}

Sumber : BPS (Badan Pusat Statistik) Tahun 2019

Berdasarkan dari tabel diatas dapat dilihat bahwa perkembangan ekspor, impor dan cadangan devisa Indonesia dari tahun 20142017. Ekspor, impor maupun cadangan devisa setiap tahunnya terus mengalami fluctuate (naik turun). Tabel diatas menunjukkan karet adalah salah satu komoditi yang utama di sektor pertanian yang jumlah volume ekspornya terbesar saat ini, bisa kita lihat pada tahun 2014 ekspor karet Indonesia sebesar US\$ 4.741.859 serta pada tahun 2017 sebesar US\$ 5.102.200 dibandingkan dengan ekspor-ekspor yang lain nya.
Fenomena atau masalah yang terjadi di tahun 2015 dimana ekspor kakao meningkat tetapi cadangan devisa menurun, hal itu juga terjadi pada tahun 2016 yaitu dimana ekspor kakao, dan karet semuanya menurun tetapi cadangan devisa meningkat, hal ini tidak sesuai dengan teori (Setiawina, 2016) ketika tingkat suatu ekspor mengalami penurunan maka pada saat itu cadangan devisa juga akan mengalami penurunan dan sebaliknya pula jika tingkat ekspor itu mengalami suatu peningkatan maka disaat itu cadangan devisa yang dimiliki juga akan ikut mengalami peningkatan.

Dari Tabel 1 maka bisa dilihat pula bahwa impor yang terbesar adalah di sektor kakao, diketahui pada tahun 2017 impor kakao sebesar US\$ 640.337 padahal diketahui lahan kakao di Indonesia ini sangat luas dan juga berlimpah sumber daya alam tetapi masih saja mengimpor kakao dari luar. Fenomena pada tahun 2015 yaitu dimana impor kakao, dan karet menurun tetapi cadangan devisa juga menurun hal ini berlawanan dengan teori yang dikemukakan oleh Benny (2013) variabel Impor berhubungan negatif terhadap suatu cadangan devisa baik itu dalam jangka pendek ataupun didalam jangka panjang.

Berdasarkan hasil tersebut, maka penulis sangat tertarik untuk melakukan penelitian ini dengan judul "pengaruh ekspor impor, kakao, dan karet terhadap cadangan devisa di Indonesia".

\section{TINJAUAN PUSTAKA}

\section{Cadangan Devisa}

Cadangan devisa yaitu keseluruhan valuta asing yang dimiliki oleh pemerintahan dan swasta dari satu negara. Semakin tinggi devisa yang didapat oleh pemerintah dan penduduk di suatu negara maka berarti semakin besar pula kemampuan negara tersebut di dalam melakukan suatu transaksi ekonomi dan keuangan internasional,jadi semakin kuat pula mata uang negara tersebut (Rizieq, 2006).

Cadangan devisa juga didefinisikan sebagai jumlah mata uang negara asing yang di cadangkan di bank sentral untuk kepentingan pembiayaan pembangunan dan kewajiban di luar negeri misalnya untuk kepentingan pembiayaan ekspor dan impor dan pembiayaan-pembiayaan lainnya kepada negara asing (Almutmainnah, 2016). Cadangan devisa adalah suatu alat pembayaran luar negeri, antara lain berupa uang kertas asing, emas dan tagihan-tagihan lainnya di dalam valuta asing kepada pihak yang ada diluar negeri (Rachbini dan Swidi, 2000).

Cadangan Devisa juga didefinisikan sebagai total dana valuta asing digunakan oleh bank pusat untuk kepentingan pembiayaan dan hak kewajiban luar negeri negara yang bersangkutan, antara lain meliputi 
pembayaran impor dan pembayaranpembayaran yang lainnya kepada pihak asing (Tambunan, 2001).

Menurut (Halwani, 2002) yaitu dikenal ada dua cadangan devisa didalam perkembangan ekonomi nasional, yakni Official Foreign Exchanged Reserved and Country Foreign Exchange Reserve, yang masing-masing memiliki cakupan yang berbeda. Pertama, adalah cadangan devisa milik satu negara yang diolah, diurus dan di tata usahakan oleh Bank Sentral yang sesuai dengan tugas yang di peroleh oleh UU No.13 Tahun 1968. Kedua, keseluruhan devisa yang dipunya oleh suatu badan, perorangan, lembaga, terutama lembaga keuangan nasional, secara moneter adalah kekayaan nasional.

Poin moneter yang paling penting yang mampu memperlihatkan kuat tidak kuatnya fundamental ekonomi negara yaitu cadangan devisa. Cadangan devisa yang cukup yakni salah satu jaminan untuk tercapainya keseimbangan moneter dan ekonomi makro di sebuah negara (Tambunan, 2001).

Maka kesimpulannya adalah cadangan devisa merupakan suatu total valuta atau mata uang asing yang disimpan oleh suatu pemerintahan dan swasta yang dicadangkan oleh bank sentral dan dapat dipergunakan di setiap waktu untuk suatu kepentingan pembiayaan pembangunan dan kewajiban luar negeri seperti pembayaran ekspor dan impor serta pembayaran lainnya, kepada pihak asing guna membiayai ketidakseimbangan neraca pembayaran,semakin banyak di negara melakukan perdagangan maka semakin banyak pula devisa yang dibutuhkan.

\section{Ekspor}

Ekspor merupakan suatu perbuatan membawa keluar barang dari daerah-daerah pabean, maksud dengan daerah pabean yaitu wilayah Republik Indonesia termasuk wilayah darat, perairan dan ruang atas nya, dan juga daerah-daerah tertentu di daerah Zona Ekonomi Eksklusif guna memenuhi ketentuan dan peraturan yang berlaku (Peraturan Pemerintahan Republik Indonesia No 2 Tahun 2009).

Menurut Amir (2004), ekspor yaitu upaya kegiatan penjualan suatu komoditas barang yang kita punya untuk negara lain, agar dapat mendapatkan pembayaran dengan valuta asing, dan juga serta bisa melakukan komoditi barang dengan menggunakan bahasa asing. Ekspor adalah negara lain membeli atas barang dari perusahaan yang ada di dalam negeri. Faktor yang paling bisa menjanjikan ekspor yaitu kesanggupan dari Negara itu terhadap mengeluarkan barang-barang yang bisa bersaing di dalam pasar luar negeri. (Sukirno, 2008).

Menurut Hariyani dan Serfianto (2010), majunya suatu negara tidak terlepas dari hubungan perdagangan di suatu negara dengan di negara lain nya, bisa dilihat dari kegiatan ekspor itu sendiri baik berupa barang ataupun jasa yang dihasilkan. Perdagangan ekspor impor adalah suatu faktor terpenting bagi negara yang tujuannya untuk mensejahterakan perekonomian dan masyarakatnya. Selain itu perdagangan luar negeri juga bisa membantu negara dalam hal usaha pembangunan dengan cara melalui promosi. Semua negara di dunia ini menjadi saling sangat ketergantungan satu dan lain dengan adanya kegiatan perekonomian (Uci, 2006).

Jadi hasil yang didapatkan dari mengeskpor yaitu berupa bentuk sejumlah nilai uang atau nama lainnya yaitu devisa, devisa ini juga adalah sumber pemasukan untuk negara. Hingga ekspor adalah suatu perbuatan perdagangan yang dapat memberi rangsangan agar menciptakan permintaan di dalam negeri yang bisa mengakibatkan munculnya indutri-industri pabrik yang besar, mengiringi dengan struktur positif yang stabil dan lembaga sosial yang efisien.

Kesimpulannya ekspor adalah kegiatan mengeluarkan barang-barang dari dalam daerah pabean untuk suatu kegiatan perdagangan dalam bentuk barang dan jasa yang nanti akan menghasilkan sumber devisa, serta bisa memperluas pasar dalam produksi barang-barang seperti : karet, kakao, dan juga yang lainnya, dengan mengikuti ketentuan-ketentuan yang telah ditentukan.

\section{Impor}

Impor adalah perbuatan membeli barang-barang dari luar ke dalam daerah pabean, transaksi kegiatan impor merupakan perdagangan dengan cara membeli barang-barang dari luar negeri ke dalam negeri atau ke daerah pabean di Indonesia dengan mematuhi ketentuan dan peraturan peundang undangan yang berlaku (Tandjung, 2011)

Menurut Susilo, (2008) impor juga bisa disebut sebagai suatu kegiatan memasukkan barang-barang dari negara (luar negeri) ke dalam daerah wilayah pabean negara. Suatu negara melakukan kegiatan impor untuk bisa memenuhi keinginan masyarakat. Barang impor adalah barang-barang yang tidak bisa diproduksi atau negara yang sudah tidak mempunyai stok barang, tetapi juga tidak bisa mencukupi kebutuhan rakyat (Ratnasari, 2012).

Dasar hukum pertama peraturan tentang Impor yang diatur didalam Keputusan Direktur Jendral Bea dan Cukai Nomor KEP.07/BC/2003. Mengenai petunjukan pelaksanaan tatacara laksana Kepabeanan di bagian impor dan keputusan Menteri Keuangan Nomor 453/KMK,04/2002 mengenai Tata laksana Kepabeanan pada bagian impor. 
Maka bisa diambil kesimpulan bahwa impor adalah suatu kegiatan atau perbuatan perdagangan internasional yang dilakukan dengan cara mengambil barang dari daerah luar wilayah kedalam pabean Indonesia yang dilakukan oleh suatu badan perorangan atau perusahaan yang bergerak dibagian ekspor impor dengan cara mematuhi dan melaksanakan ketentuan yang berlaku dan peraturan perundang-undang yang dikenakan bea masuk.

\section{Kerangka Konseptual \\ Hubungan Ekspor dengan Cadangan Devisa}

Ekspor dan cadangan devisa yaitu didalam mengerjakan ekspor maka satu negara akan mendapatkan berupa sejumlah nilai uang didalam valuta asing atau sering disebut dengan nama devisa, yang juga adalah suatu sumber pemasukan negara. Sehingga ekspor ialah perbuatan perdagangan yang dapat mendapatkan rangsangan guna menimbulkan permintaan didalam negeri yang disebabkan timbulnya industri-industri pabrik yang besar, seiring berjalan dengan struktur positif yang tetap dan lembaga sosial yang sangat efisien (Todaro:2001)

\section{Hubungan Impor dengan Tingkat Cadangan Devisa}

Hubungan impor dengan cadangan devisa ialah Impor ditentukan oleh kesanggupannya ataupun kemampuannya didalam memasarkan barang-barang yang dapat terjun dan bersaing dengan barang yang ada diluar negeri. Dengan terhambatnya aktivitas impor maka akan ikut menghambat kegiatan di dalam negeri.

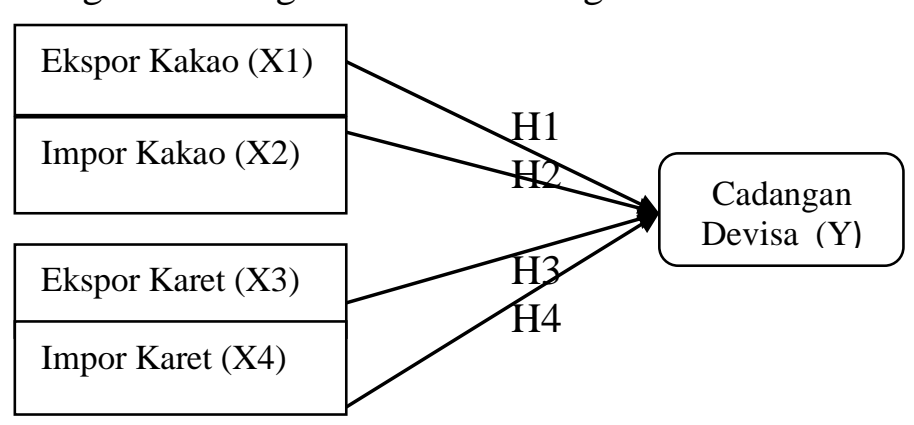

\section{Gambar 1 Kerangka Konseptual}

Kerangka konseptual menggambarkan pengaruh antara variable bebas dan variable terikat, yaitu pengaruh ekspor kakao (X1), Impor kakao (X2), ekspor karet (X3), Impor karet (X4), cadangan devisa (y)

\section{Hipotesis}

Hipotesis merupakan dugaan sementara terhadap masalah-masalah peneliti yang kebenarannya harus dilakukan pengujiannya secara empiris. Berdasarkan Rumusan Masalah, Tinjauan Pustaka, dan berbagai hasil kajian empiris yang telah dilakukan peneliti-peneliti sebelumnya, maka dapat dirumuskan hipotesis alternatif penelitian ini antara lain yaitu :

H1 : Diduga ekspor kakao terpengaruh terhadap cadangan devisa

H2 : Diduga ekspor karet terpengaruh terhadap cadangan devisa

H3 : Diduga impor kakao terpengaruh terhadap cadangan devisa

H4 : Diduga impor karet terpengaruh terhadap cadangan devisa

\section{METODE PENELITIAN}

Penelitian ini memakai data sekunder menurut runtut waktu (time series) dimana data tersebut di peroleh dari BPS (Badan Pusat Statistik) Indonesia. Adapun data yang digunakan yaitu :

1. Sumber data ekspor impor kakao dan karet periode 2005-2017 berasal dari BPS (Badan Pusat Statistik) Indonesia.

2. Sumber data cadangan devisa periode 2005-2017 berasal dari BPS (Badan Pusat Statistik) Indonesia.

\section{Operasional Variabel}

Operasional variabel merupakan petunjuk bagaimana variabel-variabel dalam penelitian diukur. Untuk memperjelas serta mempermudah pemahaman terhadap variable-variabel yang akan dianalisis dalam penelitian ini, maka operasional variabel yaitu sebagai berikut :

1. Ekspor adalah kegiatan mengeluarkan barangbarang dari dalam daerah pabean untuk suatu kegiatan perdagangan dalam bentuk barang dan jasa yang nanti akan menghasilkan sumber devisa dan dinyatakan dalam satuan Juta US\$

2. Impor adalah suatu kegiatan atau perbuatan perdagangan internasional yang dilaksanakan dengan cara mengambil barang dari daerah luarwilayah kedalam pabean Indonesia yang dilakukan oleh suatu badan perorangan atau perusahaan yang berjalan dibagian ekspor impor dengan cara mematuhi dan melaksanakan ketentuan yang berlaku dan peraturan perundang-undang yang dikenakan bea masuk dan dinyatakan dalam satuan Juta US\$

3. Cadangan Devisa adalah suatu total valuta atau mata uang asing yang disimpan oleh suatu pemerintahan dan swasta yang dicadangkan oleh bank sentral dan dapat dipergunakan di setiap waktu untuk suatu kepentingan pembiayaan pembangunan dan kewajiban luar negeri seperti pembayaran ekspor dan impor serta pembayaran lainnya, kepada pihak asing guna membiayai ketidakseimbangan neraca pembayaran, semakin banyak di negara melakukan suatu perdagangan maka semakin 
banyak pula devisa yang dibutuhkan dan dinyatakan dalam satuan Juta US\$

\section{Metode Analisis Data}

Penelitian ini menggunakan metode analisis regresi linier berganda. Analisis regresi linier berganda adalah regresi dimana variabel terikat (Y) dihubungkan atau dijelaskan oleh lebih dari satu variabel bebas, bisa dua, tiga dan seterusnya $\left(\mathrm{X}_{1}, \mathrm{X}_{2}, \mathrm{X}_{3} \ldots \mathrm{X}_{\mathrm{n}}\right)$ namun masih menunjukkan diagram hubungan yang linier (Fatmi dalam Aziz, dkk, 2016). Adapun perumusan analisis ini yaitu menggunakan metode Ordinary Least Square (OLS) sbb:

$\mathbf{Y}=\mathbf{a}+\log \beta_{1} X_{1}+\log \beta_{2} X_{2}+\log \beta_{3} X_{3}+\log$ $\beta_{4} \mathbf{X}_{4}+\mathbf{e}$

Keterangan :

$\mathbf{Y}=$ Cadangan Devisa

$\mathbf{a}=$ konstanta

$\boldsymbol{\beta}_{\mathbf{1}}, \boldsymbol{\beta}_{2}, \boldsymbol{\beta}_{3}, \boldsymbol{\beta}_{\mathbf{4}}=$ Koefisien regresi

$\log \mathbf{X}_{\mathbf{1}}=$ variableekspor kakao

$\log X_{2}=$ variableekspor karet

$\log X_{3}=$ variabel impor kakao

$\log \mathbf{X}_{\mathbf{4}}=$ variabelimpor karet

e $=$ Error Term

\section{HASIL PENELITIAN DAN PEMBAHASAN \\ Uji Normalitas}

Menurut (Suyana, 2009) uji normalitas mempunyai tujuanyaitu menguji residual dari model regresi yang dibuat apakaah didalam model regresi berdistribusi normal atau tidak. Berikut adalah hasil uji normalitas yang diperoleh dari program Eviews 9 dapat dilihat pada gambar berikut ini:

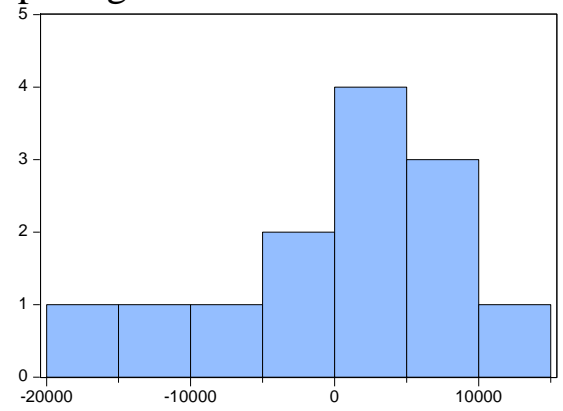

Series: Residuals Sample 20052017 Observations 13 Mean $\quad-7.38 \mathrm{e}-11$ Maximum $\quad 10379.48$

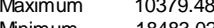
Std. Dev -18483.02 Skewness $\quad-0.972223$ $\begin{array}{ll}\text { Kurtosis } & 3.268794 \\ \end{array}$

Jarque-Bera 2.087106 $\begin{array}{ll}\text { Probability } & 0.352201\end{array}$

Sumber : Hasil Pengolahan Data, (Data diolah Tahun 2019)

Gambar 2 Hasil Uji Normalitas

Dari gambar diatas bisa dilihat bahwa grafik histrogram dapat membentuk pola distribusi simetris, jadi dapat dinyatakan residual terdistribusi normal. Menurut Gujarati (2012) Untuk mendeteksi apakah residualnya berdistribusi normal atau tidak dengan membandingkan nilai Jarque Bera dengan $\chi^{2}$ (chi-square) tabel, yaitu sebagai berikut : a. Jika nilai JB $>\chi^{2}$ (chi-square) tabel, maka residualnya berdistribusi tidak normal.

b. Jika nilai JB $<\chi^{2}$ (chi-square) tabel, maka residualnya berdistribusi normal.

Berdasarkan hasil uji normalitas menunjukkan bahwa nilai JB sebesar 2,09<7,78 sehingga dapat disimpulkan bahwa data terdistribusi normal. Hasil uji normalitas juga dapat di lihat dengan membandingkan nilai antara probabilitas JB dan nilai signifikan 5\% dengan ketentuan sebagai berikut :

a. Jika nilai Prob JB $<10 \%$, maka residualnya berdistribusi tidak normal.

b. Jika nilai Prob JB $>10 \%$, maka residualnya berdistribusi normal.

Hasil dari uji normalitas menunjukkan bahwa nilai Prob JB > 0,1 yaitu sebesar 0,352201 > 0,1 maka dapat disimpulkan bahwa residual dalam penelitian ini sudah terdistribusi dengan normal.

Uji Asumsi Klasik

Uji Multikolinieritas

Suatu model regresi dinyatakan bebas dari multikolinearitas jika mempunyai nilai korelasi $<0,80$. Hasil pengujiannya dapat dilihat pada tabel berikut :

Tabel 2

Hasil Uji Multikolinieritas

Sumber : Hasil Pengolahan Data (Data diolah Tahun 2019)

Berdasarkan hasil pada Tabel 2 di atas, dapat dilihat Breusch-Godfrey Serial Correlation LM Test:

\begin{tabular}{|lllr|}
\hline & & & \\
F-statistic & 1.28934 & & \\
& 4 & Prob. F(2,6) & 0.3421 \\
Obs*R-squared & 3.90770 & Prob. & Chi- \\
& 2 & Square(2) & 0.1417 \\
\hline \hline
\end{tabular}

dari nilai korelasi antara variabel bebas semua $<0,80$. Jadi dalam penelitian model ini sudah terbebas dari multikolineritas.

\section{Uji Autokorelasi}

Menurut Husein Umar (2011) uji autokorelasi yakni dilbuat untuk tau apakah dalam model regresi linier adanya hubungan yang kuat baik positif ataupun negatif antar data yang ada di variabel-variabel penelitian. Pengujian autokorelasi digunakan untuk mengetahui ada atau tidak autokeralasi, adapun pengujiannya sebagai berikut :
Tabel 3

Hasil Uji Autokorelasi 


\begin{tabular}{|l|l|l|l|l|}
\hline & $\mathrm{X}_{-}$ & $\mathrm{X}_{-}$ & $\mathrm{X}_{-}$ & $\mathrm{X} 4_{-}$ \\
\hline $\mathrm{X} 1_{-}$ & 1.000000 & 0.354133 & 0.196314 & 0.407954 \\
\hline $\mathrm{X} 2_{-}$ & 0.354133 & 1.000000 & -0.099629 & 0.699101 \\
\hline $\mathrm{X} 3_{-}$ & 0.196314 & -0.099629 & 1.000000 & 0.392473 \\
\hline $\mathrm{X} 4_{-}$ & 0.407954 & 0.699101 & 0.392473 & 1.000000 \\
\hline
\end{tabular}

Sumber : Hasil Pengolahan Data, (Data diolah Tahun 2019)

Berdasarkan dari Tabel 3 diatas, hasil dari uji autokorelasi dapat dilihat dari nilai Obs*Rsquared <Chi-square tabel $\left(\chi^{2}\right)$ pada df (4) dengan $\alpha=10 \%$ yaitu sebesar 3,91 $<7,78$ dan nilai probabilitas Chi-square $>\alpha$ sebesar 0,1417 $>0,1$ maka dalam model ini bahwa data sudah terbebas dari indikasi autokorelasi.

\section{Uji Heteroskedastisitas}

Uji heteroskedatisitas tujuannya untuk mengetes apakah didalam model regresi terjadi perbedaan variance dari residual satu pengamatan ke pengamatan lain (Ghozali, 2009). Jika variance dari residual satu pengamatan ke pengamatan yg lain tetap, maka disebut homokedastisitas dan jika berbeda disebut heteroskedatisitas. Adapun hasil pengujiannya sebagai berikut :

\section{Tabel 4}

\section{Hasil Uji Heteroskedastisitas}

\begin{tabular}{|llll|}
\hline Heteroskedasticity Test: White \\
\hline \hline F-statistic & 0.264205 & $\begin{array}{l}\text { Prob. F(4,8) } \\
\text { Prob.ChiSquare( }\end{array}$ & 0.8929 \\
Obs*R-squared 1.516940 & 4) & 0.8236 \\
Scaled & \multicolumn{2}{c|}{ Prob.Chi- } \\
explained SS & 0.651669 & Square(4) & 0.9572 \\
\hline \hline
\end{tabular}

Sumber : Hasil Pengolahan Data (Data diolah Tahun (2019)

Berdasarkan dari Tabel 4 diatas, hasil uji heteroskedasitas pada penelitian ini dapat dilihat dari nilai $\mathrm{Obs}^{*} \mathrm{R}$-squared sebesar 1,51 dan nilai $\chi^{2}$ tabel dengan derajat kepercayaan pada $\alpha=10 \%$ dan df (4) sebesar 7,78. Jadi hasilnya $1,51<$ 7,78 maka dalam model ini sudah terbebas dari indikasi heterokedasitas.

\section{Analisis Regresi Linier Berganda}

Uji regresi ini bertujuan untuk melihat bagaimana pengaruh variabel-variabel independen $\mathrm{kpd}$ variabel dependen. Berdasarkan dari hasil Uji analisisi regresi linier berganda dengan alat bantu komputer yang menggunakan program Eviews9, dapat dilihat pada Tabel 5, sebagai berikut :

Tabel 5

Hasil Analisis Regresi Linier Berganda

Method: Least Squares

Date: 09/23/19 Time: 18:31

Sample: 20052017

Included observations: 13

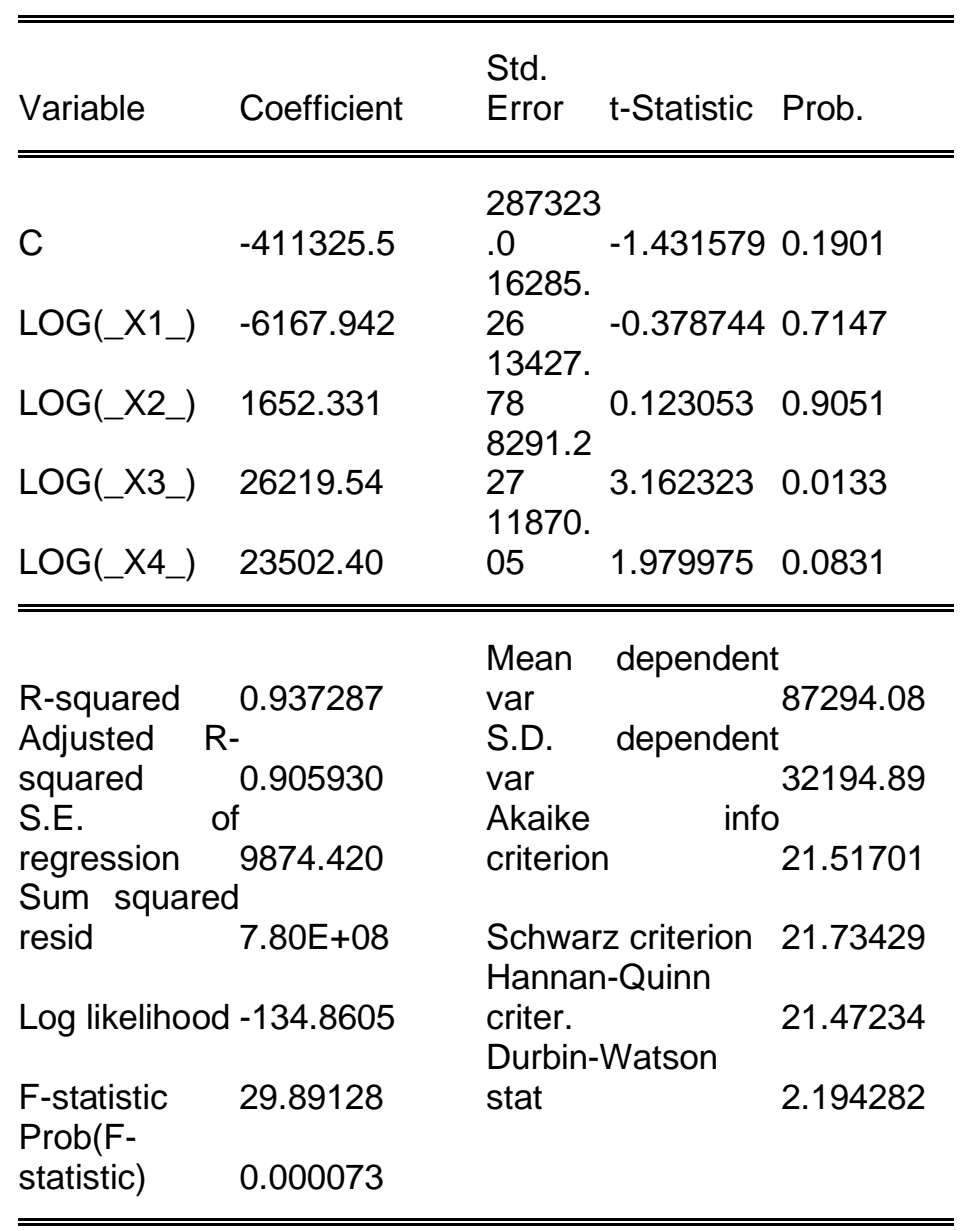

Sumber : Hasil Pengolahan Data (Data diolah Tahun 2019)

Dari persamaan model regresi diatas maka interpretasi hasil penelitian sebagai berikut :

1. Konstanta $(\mathrm{a})=\mathrm{US} \$-411325,5$

Apabila variabel Ekspor Kakao,Ekspor Karet, Impor Kakao, dan Impor Karet bernilai konstan (Nol), maka cadangan devisa Indonesia juga akan konstan sebesar US\$ -411325,5

2. Parameter ekspor kakao $\left(X_{1}\right)=\mathrm{US} \$-6167,942$

Apabila ekspor kakao meningkat sebesar US\$ 1 maka cadangan devisa Indonesia akan mengalami peningkatan sebesar US\$ 6167,942.

3. Parameter ekspor karet $\left(X_{2}\right)=\mathrm{US} \$ 1652,331$ 
Apabila ekspor karet meningkat sebesar US\$ 1 maka cadangan devisa Indonesia akan turun sebesar US\$ 1652,331.

4. Parameter impor kakao $\left(X_{3}\right)=$ US\$ 26219,54

Apabila impor kakao meningkat sebesarUS\$ 1, maka cadangan devisa Indonesia akan mengalami peningkatan sebesar US\$26219,54.

5. Parameter impor karet $\left(X_{4}\right)=\mathrm{US} \$ 23502,40$ Apabila impor karet meningkat sebesar US\$1 maka cadangan devisa Indonesia akan naik sebesar US\$23502,40

\section{Pengujian Hipotesis}

\section{Pengujian Parsial (Uji t)}

Uji statistik merupakan pengujian terhadap koefisien dari variabel bebas secara parsial. Uji ini dilakukan untuk melihat tingkat signifikansi dari variabel bebas secara individu dalam mempengaruhi variabel terikat. Pengujian ini dilihat dengan cara membandingkan $t_{\text {statistik }}$ dengan $t_{\text {tabel }}$. $T$-tabel diperoleh dengan cara $\mathrm{df}$ $(n-k)=(13-5)=8$ pada $\mathrm{df}(8) \alpha=10 \%$ sebesar $1,39682=1,40$.

Konstanta (a) $=-1,43$ Oleh karena thitung $>$ $\mathrm{t}_{\text {tabel }}$ atau $-1,43>1,40$ maka tolak $H_{0}$ dan terima $H_{a}$ yang berarti bahwa ekspor kakao, ekspor karet, impor kakao, dan impor karet berpengaruh signifikan dan positif kepada cadangan devisa.

Parameter $\left(X_{1}\right)=-0,38$ Oleh karena $t_{\text {hitung }}<$ $\mathrm{t}_{\text {tabel }}$ atau $-0,38<1,40$ maka terima $H_{0}$ dan tolak $H_{1}$ yang berarti bahwa ekspor kakaotidak berpengaruh signifikan dan negatif terhadap cadangan devisa.

Parameter $\left(X_{2}\right)=0,12$ Oleh karena $t_{\text {hitung }}<$ tabel atau $0,12<1,40$ maka terima $H_{0}$ dan tolak $H_{2}$ yang berarti bahwa ekspor karet tidak berpengaruh signifikan dan negatif terhadap cadangan devisa.

Parameter $\left(X_{3}\right)=3,16$ Oleh karena thitung $>$ $\mathrm{t}_{\text {tabel }}$ atau 3,16 $>1,40$ maka tolak $H_{0}$ dan terima $H_{3}$ yang berarti bahwa impor kakao berpengaruh signifikan dan positif terhadap cadangan devisa.

Parameter $X_{4}=1,97$ Oleh karena $t_{\text {hitung }}>$ $\mathrm{t}_{\text {tabel }}$ atau 1,97 $>1,40$ maka tolak $H_{0}$ dan terima $H_{4}$ yang berarti bahwa impor karet berpengaruh signifikan dan positif terhadap cadangan devisa di Indonesia.

\section{Pengujian Simultan (Uji F)}

Uji f dilakukan untuk melihat pengaruh variabel bebas terhadap variabel terikat secara bersama-sama dengan membandingkan antara $F_{\text {hitung }}$ dengan $F_{\text {tabel }}$, apabila $F_{\text {hitung }}>F_{\text {tabel }}$ maka variabel bebas berpengaruh secara bersamasama terhadap variabel terikat. $F_{\text {tabeldiperoleh }}$ dengan cara df $(\mathrm{k}-1)(\mathrm{n}-\mathrm{k})=(5-1)(13-5)=(4)(8)$, pada tingkat kepercayaan $\alpha=10 \%$ adalah sebesar 2,81 . $F_{\text {hitung }}$ Statistik $=29,89$ Oleh karena $F_{\text {hitung }}>F_{\text {tabel }}$ atau $29,89>2,81$ maka tolak $\mathrm{H}_{0}$ dan terima $\mathrm{H}_{\mathrm{a}}$ yang berarti bahwa secara serentak ekspor kakao, ekspor karet, impor kakao, dan impor karet berpengaruh signifikan dan positif terhadap cadangan devisa di Indonesia.

\section{Koefisien Determinasi $\left(\mathbf{R}^{2}\right)$ dan Korelasi $(\mathbf{R})$ Koefisien Determinasi $\left(\mathbf{R}^{2}\right)$}

Koefisien Koefisien Determinasi $\left(\mathrm{R}^{2}\right)$ pada intinya mengukur seberapa jauh kemampuan model dalam menerangkan variasi variabel dependen(Ghozali, 2009). Nilai koefisien determinasi yaitu antara 0 (nol) dan 1 (satu). Nilai $\mathrm{R}^{2}$ yang kecil berarti kemampuan variable-variabel independen dalam menjelaskan variasi variabel dependen sangat terbatas. Nilai yang mendekati satu berarti variable-variabel independen memberikan hampir semua informasi yang diperlukan untuk memprediksi variasi variabel dependen (Ghozali, 2009 ).

Koefisien determinasi $\left(R^{2}\right)$ yang diperoleh adalah sebesar 0,8989. Jadi besarnya pengaruh ekspor kakao, ekspor karet, impor kakao, dan impor karet terhadap cadangan devisa di Indonesia adalah sebesar 0,9059 $(90,59 \%)$. Sedangkan yang dipengaruhi oleh variabel lain diluar model ini adalah sebesar 1-0,9059=0,0941 $(09,41 \%)$.

\section{Koefisien Korelasi (R)}

Koefisien korelasi merupakan suatu cara untuk mengetahui kuat atau tidaknya hubungan antara variabel independen $(\mathrm{X})$ dan variabel dependen $(\mathrm{Y})$, apabila dinyatakan dengan fungsi linear dan di ukur dengan suatu nilai yang disebut koefisien korelasi. Berikut pengujian koefisien korelasi :

Koefisien korelasi $(\mathrm{R})=\sqrt{R^{2}}=\sqrt{0,9373}=0,9681$ $(96,81 \%)$. Jadi hubungan antara ekspor kakao, ekspor karet, impor kakao, dan impor karet terhadap cadangan devisa di Indonesia berhubungan sangat erat (sangat kuat) secara positif, karena nilai korelasi sebesar 0,9518 mendekati positif $1(+1)$.

\section{Pembahasan}

\section{Pengaruh Ekspor Kakao Terhadap Cadangan Devisa}

Berdasarkan hasil penelitian yang sudah diuji dengan memakai model analisis yaitu regresi linier berganda. Maka diperoleh hasil dari regresi linier berganda adalah ekspor kakao tidak berpengaruh secara signifikan dan negatif terhadap cadangan devisa di Indonesia. Hal ini sesuai dengan penelitian yang dilkerjakan oleh Citra, (2018) yang mengatakan ekspor tidak berpengaruh terhadap cadangan devisa. Karena penyebab nya apabila Indonesia sering melakukan ekspor barang ke negara lain maka Indonesia akan memperoleh devisa dari negara pengimpor, jadi semakin banyak barang yang diekspor maka devisa diperoleh juga semakin banyak. Dengan semakin 
meningkat nya nilai ekspor, maka menunjukkan bahwa negara tersebut semakin banyak penerima pemasukkan dari negara luar, atau biasa disebut menerima devisa atau valuta asing yang merupakan salah satu sumber pendapatan negara.

\section{Pengaruh Ekspor karet Terhadap Cadangan Devisa}

Dari hasil penelitian yang sudahdilakukan dengan menggunakan model analisis regresi linier berganda. Maka diperoleh hasil adalah ekspor karet tidak berpengaruh secara signifikan dan negatif terhadap cadangan devisa di Indonesia karena banyak sekali permintaan ekspor karet tidak sesuai seperti yang diharapakan, maka pemerintah banyak merasakan penurunan yang sangat drastis.

Hasil penelitian ini sama dengan yang dilakukan oleh Citra (2018) yang menyatakan bahwa ekspor tidak berpengaruh terhadap cadangan devisa. Hal ini menyebabkan berubahnya nilai mata uang, berimbas ke simpanan giro bank umum dan berdaqmpak pada cadangan devisa. Dengan kata lain, semakin meninggi tingkat inflasi yang terjadi maka akan bertambah nilai suatu mata uang karena meningkat harga barang dan jasa di pasarann. Cadangan devisa memiliki peran yang penting untuk posisi nilai tukar suatu negara. Semakin banyak devisa yang dimiliki oleh pemerintah dan penduduk suatu negara maka makin besar kemampuan negara tersebut melakukan kegiatan ekonomi hingga makin kuat pula nilai mata uang. Jadi semakin tinggi ekspor dan nilai tukar mata uang negara, memperlihatkan bahwa makin kuatnya perekonomian suatu negara, hingga dapat meningkatkan cadangan devisa.

\section{Pengaruh Impor kakao Terhadap Cadangan Devisa}

Berdasarkan hasil penelitian yang telah dilakukan dengan menggunakan model analisis regresi linier berganda. Maka diperoleh hasil dari regresi linier berganda adalah impor kakao berpengaruh secara signifikan dan positif terhadap cadangan devisa di Indonesia. Penelitian ini sejalan dengan hasil penelitian Benny, (2013) secara parsial variabel impor berpengaruh signifikan terhadap cadangan devisa di Indonesia. semakin tinggi nilai impor maka akan mengurangi persediaan cadangan devisa.

\section{Pengaruh Impor karet Terhadap Cadangan Devisa}

Berdasarkan hasil penelitian yang telah dilakukan dengan menggunakan model analisis regresi linier berganda. Maka diperoleh hasil dari regresi linier berganda adalah variabel impor berpengaruh positif terhadap cadangan devisa Indonesia. Hasil penelitian ini sama dengan penelitian yang dilakukan oleh Benny (2013) menyatakan impor berpengaruh positif terhadap cadangan devisa Indonesia.

\section{KESIMPULAN DAN SARAN}

\section{Kesimpulan}

Dari hasil penelitian yang telah diteliti melalui perolehan data dari Badan Pusat Statistik (BPS) dan hasil olahan dengan regresi linier berganda maka bisa disimpulkan diantaranya yakni:

1. Hasil yang didapatkan variabel ekspor kakao tidak berpengaruh signifikan dan negatif terhadap cadangan devisa di Indonesia.

2. variabel ekspor karet tidak berpengaruh signifikan dan negatif terhadap cadangan devisa di Indonesia.

3. Secara bersama-sama variabel impor kakao dan impor karet berpengaruh signifikan dan positif terhadap cadangan devisa di Indonesia.

\section{Saran}

Berdasarkan kesimpulan yang telah disimpulkan di atas maka adapun saran pada penelitian ini adalah:

1. Diharapkan bagi pemerintah agar dapat meningkatkan perekonomian Indonesia dari menambah ekspor dan mengurangi impor, dengan cara memperluas negara tujuan ekspor serta meningkatkan kualitas produk ekspor dalam negeri, Karena kelebihan ekspor daripada impor akan menguntungkan pemerintah dengan bertambahnya cadangan devisa. Selain itu, pemerintah sebaiknya juga dapat mengurangi berhutang dari luar negeri, walaupun pada awalnya menambah cadangan devisa namun ketika pembayarannya akan mengurangi cadangan devisa belum lagi bunga dari hutang tersebut.

2. Untuk Peneliti selanjutnya yang melakukan penelitian sejenis, penulis menyarankan agar menambah variabel lain yg berpengaruh ke pertumbuhan ekonomi danjuga menggunakan metode penelitian lain dalam menganalisis data.

\section{DAFTAR PUSTAKA}

Agustina dan Reny, (2014) Pengaruh Ekspor, Impor, Nilai Tukar Rupiah, Dan Tingkat Inflasi terhadap Cadangan Devisa di Indonesia. Volume 04 No 02 Oktober Jurnal Wira Ekonomi Mikrosil. 
Alinda Nurul, (2013) Analisis Faktor-Faktor yang Mempengaruhi Ekspor Karet di Indonesia. Vol 11 No 01 Juni Jurnal Ekonomi Pembangunan FEB UMM

Basri, (2016) Analisis Pengaruh Ekspor dan Impor Terhdap Cadangan Devisa, Program Studi Ekonomi Pembangunan Fakultas Ekonomi.

Benny, Jimmy (2013) Ekspor dan Impor Pengaruhnya Terhadap Cadangan Devisa di Indonesia Vol 1 No.4 Desember 2013, Hal. 1406-1415 Fakultas Ekonomi Dan Bisnis, Jurusan Ekonomi Pembangunan, Universitas Samratulangi Manado

Juniantara, I. P. K., \& Budhi, M. K. S. (2012) Pengaruh Ekspor, Impor Dan Kurs Terhadap Cadangan Devisa Nasional Periode 1999-2010. E-Jurnal Ekjonomi Pembangunan Univeristas Udayana, 1 (1), 32-38

Maulana, Arif and Kartiasih, Fitri (2017) "Analisis Ekspor Kakao Olahan Indonesia Ke Sembilan Negara Tujuan Tahun 2000-2014 J. Vol 17, No 2 Jurnal Ekonomi dan Pembangunan Indonesia

Kartika Dwi, (2016) "The Effect of Export, Impor and Investment ti Economic Growth of Riau Island Indonesia, "int. J. Econ. Financ. Issues.

Kiranta Febri, (2014) Analisis Tingkat Daya Saing Ekspor Biji Kakao Indonesia Tahun 2007-2012. ISSN: 2303-0178 EJurnal EP Unud, 3 (11) Jurusan Ekonomi Pembangunan Fakultas Ekonomi dan Bisnis Universitas Udayana

Kurniawan Edo, (2012) Pengaruh Produksi Karet, Kurs Dollar Amerika Serikat Dan Ekspor Karet Terhadap Cadangan Devisa di Indonesia. ISSN: 2303-0178 E-Jurnal EP Unud, Bali, Indonesia

Luthfi Safitri, (2018). Analisis Kinerja Ekpsor Dan Impor Tembakau Indonesia Periode 2000-2009. Media Ekonomi Vol. 19 No 02 Agustus Fakultas Ekonomi Universitas Trisakti.

Luqman Muhammad, (2016) Pengaruh Produksi Harga dan Nilai tukar terhadap volume Ekspor. Volume 40 No. 02 November Fakultas Ilmu admimistrasi $\mathrm{U}_{1} \cdot{ }^{\cdot} \mathrm{s}$ Brawijawa. 66

Novianti Tanti, (2008) Analisis Penawaran Ekspor Karet Alam Indonesia Ke Negara China. Vol 5 No 1 Maret Jurnal Manajemen Agribisnis IPB.

Pinem(2009), Analisis Pengaruh Ekspor, Impor, Kurs Nilai Tukar Skripsi Oleh : Guna memenuhi Salah Satu Syarat Untuk Memperoleh Gelar Sarjana Ekonomi Medan, "Universitas Sumatera Utara Fakultas Ekonomi., Vol 1, no. 1

Rahardianto, D. 2008. Principal Componen Analysis (PCA) Sebagai Metode Jitu Untuk Mengatasi Masalah Multikolineritas.

Ridho Muhammad, (2013)Dampak Penerapan Kuota Impor Terhadap Permintaan Karet Alam Indonesia Oleh Negara China. Vol 1 No 02, Desember Jurnal, Agribisnis Indonesia Institut Pertanian Bogor.

Silvia, Atika and A. Syaad (2014) "Analisis Prospek Ekspor Karet Indonesia Ke jepang, vol. 3, no. 1, 2014. Jurnal ekonomi Pembangunan.

Simanjutak, Payaman (2005) Pengantar Ekonomi SDA. Jakarta: Rajawali Press

Sukirno, Sadono (2011) Makro Ekonomi Teori Pengantar PT. Raja Grafindo Perkasa. Jakarta

Sukirno, Sadono (2000) Pengantar Teori Mikro Ekonomi Edisi Kedua Jakarta : Rajawali Press

Suryanto, (2016) Pengaruh Nilai tukar, Produk Domestik Bruto Dan Produksi Karet Terhadap Ekspor Karet Di Indonesia. Volume VI NO 02 Desember Jurnal Ilmu Politik Dan Komunikasi.

Todaro, M.P dan Stephen C.S (2003) Pembangunan Ekonomi Didunia Ketiga Edisi Kedelapan. Jakarta: Erlangga

Link:

http://news.detik.com/kolom/d-4321119/revitalisasidata-kakao

http://citrodunia.blogspot.com/2013/02/

http://dickyrahardi.wordpress.com/2006/2/9/pricipalcomponentanalysis-pca-sebagai-metode-jituuntuk-mengatasimultikolineritas

http://junaidichaniago.files.wordpress.com/2010/04/tab el-f-0-10.pdfpage $=2 \&$ zoom $=$ auto, $-39,384$ 